University of Nebraska - Lincoln

DigitalCommons@University of Nebraska - Lincoln

\title{
Reduction of mosquito biting pressure by timed-release $0.3 \%$ aerosolized geraniol
}

\author{
Edita E. Revay \\ Bruce Rappaport Faculty of Medicine \\ Amy Junnila \\ Hebrew University of Jerusalem \\ Daniel L. Kline \\ United States Department of Agriculture-ARS-Center for Medical \\ Rui-De Xue \\ Anastasia Mosquito Control District \\ Ulrich R. Bernier \\ University of Florida, ubernier@gainesville.usda.ufl.edu \\ See next page for additional authors
}

Follow this and additional works at: https://digitalcommons.unl.edu/usdaarsfacpub

Part of the Agricultural Science Commons

Revay, Edita E.; Junnila, Amy; Kline, Daniel L.; Xue, Rui-De; Bernier, Ulrich R.; Kravchenko, Vasiliy D.; Yefremova, Zoya; and Müller, Günter, "Reduction of mosquito biting pressure by timed-release $0.3 \%$ aerosolized geraniol" (2012). Publications from USDA-ARS / UNL Faculty. 947.

https://digitalcommons.unl.edu/usdaarsfacpub/947

This Article is brought to you for free and open access by the U.S. Department of Agriculture: Agricultural Research Service, Lincoln, Nebraska at DigitalCommons@University of Nebraska - Lincoln. It has been accepted for inclusion in Publications from USDA-ARS / UNL Faculty by an authorized administrator of DigitalCommons@University of Nebraska - Lincoln. 


\section{Authors}

Edita E. Revay, Amy Junnila, Daniel L. Kline, Rui-De Xue, Ulrich R. Bernier, Vasiliy D. Kravchenko, Zoya Yefremova, and Günter Müller 


\title{
Short Communication
}

\section{Reduction of mosquito biting pressure by timed-release $0.3 \%$ aerosolized geraniol}

\author{
Edita E. Revay ${ }^{\mathrm{a}}$, Amy Junnila ${ }^{\mathrm{b}}$, Daniel L. Kline ${ }^{\mathrm{c}}$, Rui-De Xue ${ }^{\mathrm{d}}$, Ulrich R. Bernier ${ }^{\mathrm{c}}$, Vasiliy D. Kravchenko ${ }^{\mathrm{e}}$, \\ Zoya A. Yefremova ${ }^{\mathrm{e}}$, Günter C. Müller ${ }^{\mathrm{b}, *}$ \\ a Department of Anatomy and Cell Biology, Bruce Rappaport Faculty of Medicine, Technion, Haifa 34995, Israel

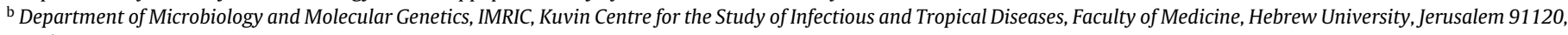 \\ Israel \\ ' United States Department of Agriculture-ARS-Center for Medical, Agricultural, and Veterinary Entomology, Gainesville, FL, USA \\ d Anastasia Mosquito Control District, 500 Old Beach Road, St. Augustine, FL 32080, USA \\ e Department of Zoology, George S. Wise Faculty of Life Sciences, Tel Aviv University, Tel Aviv 69978, Israel
}

\section{A R T I C L E I N F O}

\section{Article history:}

Received 28 February 2012

Received in revised form 11 June 2012

Accepted 23 June 2012

Available online $\mathrm{xxx}$

\section{Keywords:}

Geraniol

Culex pipiens

Aedes albopictus

Botanical repellent

Area repellent

Israel

\begin{abstract}
A B S T R A C T
We conducted a study to determine the degree of personal protection provided by the Terminix ${ }^{\circledR}$ ALLCLEAR $^{\circledR}$ Mosquito Mister - Lantern Edition. This outdoor unit was operated to disperse an aerosolized aqueous $0.3 \%$ geraniol emulsion in timed-release intervals of 5.0, 7.5, and $10.0 \mathrm{~min}$. Human volunteers participated in landing catch experiments to test the effect of geraniol sprayed at pre-set time intervals, at two distances: (1) $18 \mathrm{ft}$ ( $5.49 \mathrm{~m}$ ), the maximum effective distance claimed by the manufacturer, and (2) $9 \mathrm{ft}(2.74 \mathrm{~m})$, half the effective distance from the unit. When aerosolized geraniol was dispensed, reductions in biting pressure (landing, probing and biting mosquitoes) of Culex pipiens and Aedes albopictus, at all times and distances, were evident compared to dispensation of the water spray control. The degree of protection correlated well with the distance from the subject and the time interval of releases. The $5 \mathrm{~min}$ time interval mode reduced overall biting pressure by more than $90 \%$ at $9 \mathrm{ft}(2.74 \mathrm{~m})$ and $18 \mathrm{ft}(5.49 \mathrm{~m})$. Reduction of biting pressure in the 7.5 min mode was still well over $80 \%$ and even in the 10 min mode, overall protection was slightly above $80 \%$ at a distance of $9 \mathrm{ft}$. The lowest but still reasonable protection level was observed in the 10 min mode, at the periphery of the area the unit claims to protect $\left(300 \mathrm{ft}^{2}\right)$, with a biting pressure reduction of approximately two-thirds.
\end{abstract}

(c) 2012 Elsevier B.V. All rights reserved.

\section{Introduction}

The global threat of mosquito-borne diseases, such as West Nile Virus (WNV) and Malaria, and their associated morbidity and mortality highlights the need for effective insect repellents. It is therefore important to know which repellent products can be relied on to provide consistent and prolonged protection from bites. In recent years, botanical insect repellents have become increasingly popular as viable alternatives to synthetic chemical pest repellents (Wirtz et al., 1980; Omolo et al., 2004; Kaufman et al., 2010) because they reputedly pose little risk to the environment or human health. Specifically, many claims have been made regarding the repellent properties of citronella essential oil and various terpene alcohols such as geraniol and linalool (Choi et al., 2002; Barnard and Xue, 2004; Park et al., 2005).

Numerous "alternative" botanical products (Cox, 2005), many in the form of area repellents, have been marketed to consumers

\footnotetext{
* Corresponding author. Tel.: +972 525257521.

E-mail address: guntercmuller@hotmail.com (G.C. Müller).
}

0001-706X/\$ - see front matter (c) 2012 Elsevier B.V. All rights reserved. http://dx.doi.org/10.1016/j.actatropica.2012.06.008 mainly to control nuisance mosquitoes. In developed countries, these products are widely used by consumers trying to rid themselves of mosquitoes and biting flies in back yards, but one of the concerns with outdoor use is that the repellent molecules may be diluted by airflow or driven away by change in wind direction.

Ideal area repellents need an optimal degree of volatility, making it possible for an effective vapor concentration to be maintained (Gerberg and Novak, 2007; Moore et al., 2007). Vapors should also repel multiple species of biting insects, cause no irritation to the skin or mucous membranes and be nontoxic to humans and animals. Botanical repellents in the form of candles, diffusers, and misters could potentially provide sufficient protection provided they fit the above criteria.

The purpose of this study was to determine the degree of personal protection afforded by a timed-released, water-based emulsion of $0.3 \%$ geraniol mist dispensed by a pressurized spray can in an area of high mosquito biting pressure in Israel. To ensure quality control, the current study adheres to the above-mentioned EPA guidelines, as well as to currently accepted standards for testing insect repellents (EPA, 1999; Govere and Durrheim, 2007; Barnard et al., 2007).

This article is a U.S. government work, and is not subject to copyright in the United States. 


\section{Materials and methods}

\subsection{Equipment}

The apparatus tested in this study was the Terminix ${ }^{\circledR}$ ALLCLEAR $^{\circledR}$ Mosquito Mister - Lantern Edition that releases aerosolized repellent at three pre-programmed intervals of 5.0, 7.5, or $10.0 \mathrm{~min}$. The unit is also equipped with a remote control that allows the user to release repellent on demand if desired.

The aqueous $0.3 \%$ geraniol emulsion was contained in a pressurized spray can within the Mosquito Mister. The unit was charged and operated with a single spray can for each of the three timedspray periods. The aerosol products were stored less than 1 month in the laboratory at room temperature (approx. $23^{\circ} \mathrm{C}$ ) before they were tested.

\subsection{Volunteers}

Six volunteers, four male and two female professional entomologists/medics, provided their written informed consent to participate in this study. As part of the consent process, the participants were fully advised of the nature and purposes of the test and the possible health risks from exposure to chemicals and insect populations. They were required to avoid alcohol, caffeine, and fragrance products (e.g., perfume, cologne, hairspray, lotion, etc.) during the entire test period. For the tests, volunteers were seated in chairs, remaining as motionless as possible, facing towards the mister, with one arm extended at a $45^{\circ}$ angle, resting on thighs, in front of them. The skin outside the test area (including the hand, the forearm, and bicep) was covered with regular clothes to protect from mosquito bites; volunteers wore long trousers and short-sleeved shirts. Since tests were conducted just after sunset, the volunteers and assistants were situated approximately $2.4 \mathrm{~m}$ from a 50 -W garden lantern, which allowed them to identify and count landing mosquitoes.

\subsection{Test site and weather conditions}

Tests were performed on the northern Mediterranean coastal plain of Israel in suburban Haifa ( $32^{\circ} 48^{\prime} 56^{\prime \prime}$ North, 34 $59^{\prime} 21^{\prime \prime}$ East). The study took place in late November 2011 and experiments were conducted in the early evening from 18:00 to 21:00 local time (just after sunset). The test and the control sites were surrounded on all sides either by buildings or vegetation such that air movement was minimal. Weather conditions were consistent throughout the study with early evening temperatures ranging from 20 to $24^{\circ} \mathrm{C}$ and periods with a few clouds. Smoke cartridges were placed at a distance of $100 \mathrm{~m}$ from the experimental site to verify airflow and were carefully monitored during the experiments. No unfavorable weather conditions were observed during the trial periods.

In accordance with United States Environmental Protection Agency (US EPA) recommendations (EPA, 1999), a site was selected that has a minimum biting pressure ( $1 \mathrm{bite} / \mathrm{min}$ ) with at least two different mosquito genera and species. Common mosquitoes at the test and nearby control site are Culex pipiens and Aedes albopictus.

\subsection{Experimental setup}

To determine the area coverage of aerosol from the Mosquito Mister, the unit was mounted on a pole $1.6 \mathrm{~m}$ above the ground, and letter-sized overhead projector acetate sheets (Din A4 plastic sheets, 100 pieces) were mounted on wooden poles, $0.5 \mathrm{~m}$ above the ground, arranged in a $10 \mathrm{~m} \times 10 \mathrm{~m}$ square in front of the unit, at a density of one sheet per $\mathrm{m}^{2}$. The unit was mounted at the edge of the square, halfway between the corners ( $5 \mathrm{~m}$ ) and adjusted to spray towards the center of the square. After three sprays, the sheets were recovered and examined with a $3 \times$ magnifying glass for droplet coverage. Sheets with 10 or more droplets were regarded as positive for coverage with the misting unit. The procedure was replicated six times.

We tested the repellency rate for each of the three programmable time intervals $(5.0,7.5$ and $10.0 \mathrm{~min}$ ) by situating volunteers at distances of $9 \mathrm{ft}(2.74 \mathrm{~m})$ and $18 \mathrm{ft}(5.49 \mathrm{~m})$ from the unit, resulting in six trials; $n=18$ at $9 \mathrm{ft}(2.74 \mathrm{~m})$ and $n=18$ trials at $18 \mathrm{ft}(5.49 \mathrm{~m})$ over a period of 3 consecutive days. Each evening, we tested one of the three programmable-release time intervals; landing rates were evaluated for five min, which enabled the group of volunteers to finish one trial in half hour.

On the first day, two spray can-equipped units were randomly assigned to the volunteers. The misters (with the assigned cans either active - filled with geraniol, or control - filled with water) were rotated on successive trial days through the two selected sites. The participants were not informed which mister was equipped with active material and which not. In every trial, all six volunteers rotated three times trough the treated station and three times through the control station resulting in 18 counts at $9 \mathrm{ft}(2.74 \mathrm{~m})$ from the unit and 18 counts at $18 \mathrm{ft}(5.49 \mathrm{~m})$ from the unit, both at the testing site and at the control sites. The participants alternated back and forth between the treated and control areas.

All mosquitoes that landed were counted, even if they took flight immediately. Landing, probing and biting events (in time intervals of $5 \mathrm{~min}$ ) on the arm were, counted, pooled, and recorded on data sheets by two assistants standing behind the volunteers at a distance of about $1 \mathrm{~m}$.

\section{Results}

\subsection{Mosquito composition}

One day prior to the trials, we collected a base-line sample of 100 mosquitoes on human bait from 18:00 to 21:00 h. The catch was composed of $68 \mathrm{Cx}$. pipiens and $32 \mathrm{Ae}$. albopictus. Both species could be easily and reliably identified on sight while landing.

\subsection{Area coverage}

Area coverage was considered positive for all acetate square sheets covered with 10 or more droplets. The average area coverage of the mister unit was calculated over six repetitions and was determined to be $52.33 \mathrm{~m}^{2}\left(563.28 \mathrm{ft}^{2}\right)$. The highest droplet densities were observed in a cone shaped area of $120^{\circ}$ and towards the center of the $10 \mathrm{~m} \times 10 \mathrm{~m}$ square. Densities of 10 or more droplets were observed up to the most distant side of the square $(10 \mathrm{~m})$.

The product claims area coverage of $300 \mathrm{ft}^{2}\left(27.87 \mathrm{~m}^{2}\right)$ and accordingly we adjusted our experiments to the claims and tested for an area of $120^{\circ}$ with a total area coverage $339.29 \mathrm{ft}^{2}\left(31.52 \mathrm{~m}^{2}\right)$. This is one-third (or $120^{\circ}$ ) of a full circle with a radius of $18 \mathrm{ft}$ $(5.49 \mathrm{~m})$. We also decided to test efficacy at $9 \mathrm{ft}(2.74 \mathrm{~m})$ from the unit, as this is half the maximum distance reached by the spray. The area covered at this distance is $84.82 \mathrm{ft}^{2}\left(7.88 \mathrm{~m}^{2}\right)$.

\subsection{Reduction of biting pressure}

The degree of protection supplied by the Mosquito Mister correlates well with the distance from the subject and the time interval of releases (Tables 1 and 2). We tested the unit under fairly high biting pressure conditions (i.e., high rate of landing, probing and biting mosquitoes) and the 5 min time interval had an overall biting pressure reduction rate of more than $90 \%$ at $9 \mathrm{ft}(2.74 \mathrm{~m})$ and $18 \mathrm{ft}$ (5.49 $\mathrm{m}$ ) distances (Tables 1 and 2 ). In the $7.5 \mathrm{~min}$ interval mode, the overall biting pressure reduction was still well over $80 \%$ and even in the 10 min mode, overall protection was slightly above $80 \%$ 
Table 1

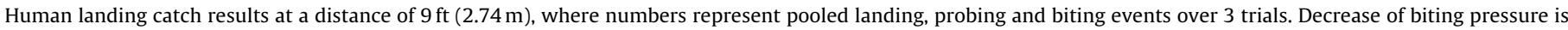
presented as percentage reduction.

\begin{tabular}{|c|c|c|c|c|c|c|c|c|c|}
\hline \multirow[t]{2}{*}{ Mode } & \multicolumn{3}{|c|}{ CX. pipiens } & \multicolumn{3}{|c|}{ Ae. albopictus } & \multicolumn{3}{|c|}{ Total mosquitoes } \\
\hline & Control & Treated & Reduction & Control & Treated & Reduction & Control & Treated & Reduction \\
\hline $5.0 \mathrm{~min}$ & 152 & 1 & $99.34 \%$ & 113 & 3 & $97.34 \%$ & 265 & 4 & $98.49 \%$ \\
\hline $7.5 \mathrm{~min}$ & 127 & 11 & $91.34 \%$ & 77 & 9 & $88.31 \%$ & 204 & 20 & $90.20 \%$ \\
\hline $10.0 \mathrm{~min}$ & 214 & 34 & $84.11 \%$ & 162 & 39 & $75.93 \%$ & 376 & 73 & $80.11 \%$ \\
\hline
\end{tabular}

Table 2

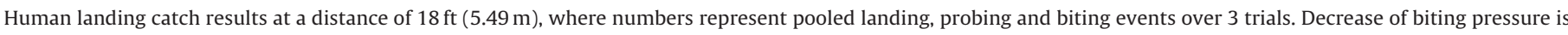
presented as percentage reduction.

\begin{tabular}{|c|c|c|c|c|c|c|c|c|c|}
\hline \multirow[t]{2}{*}{ Mode } & \multicolumn{3}{|c|}{ Cx. pipiens } & \multicolumn{3}{|c|}{ Ae. albopictus } & \multicolumn{3}{|c|}{ Total mosquitoes } \\
\hline & Control & Treated & Reduction & Control & Treated & Reduction & Control & Treated & Reduction \\
\hline $5.0 \mathrm{~min}$ & 157 & 8 & $94.99 \%$ & 123 & 5 & $95.93 \%$ & 280 & 13 & $95.53 \%$ \\
\hline $7.5 \mathrm{~min}$ & 139 & 23 & $83.45 \%$ & 89 & 18 & $79.78 \%$ & 228 & 41 & $82.02 \%$ \\
\hline $10.0 \mathrm{~min}$ & 252 & 79 & $68.65 \%$ & 155 & 57 & $63.23 \%$ & 407 & 136 & $66.59 \%$ \\
\hline
\end{tabular}

at a distance of $9 \mathrm{ft}$ (Table 1 ). The lowest but still reasonable protection level was observed in the 10 min mode, at the periphery of the area the unit claims to protect, with a biting pressure reduction of two-thirds (Table 2 ).

\section{Discussion}

In this study, much care was taken to select areas with appropriate and stable weather conditions. It was especially important to work in an environment of no or minimal air movement. Under these conditions, the Mosquito Mister dispensing a $0.3 \%$ waterbased geraniol emulsion provided a steady and satisfactory level of protection from biting mosquitoes (Tables 1 and 2). The results show that with little or no air movement a person can be well protected as long as they are within the plume of the repellent mist.

Choice of active ingredient is an important factor in the performance of an area repellent system. Geraniol-based products are available commercially in several countries and in several forms. A plant-derived alcohol, geraniol is considered completely safe for use and appears on the US Food and Drug Administration (US FDA) Generally Regarded as Safe (GRAS) list and is classified by the US EPA as a minimum risk pesticide under section 25(b) of the Federal Insecticide, Fungicide, and Rodenticide Act (FIFRA). It has been demonstrated to be effective in repelling mosquitoes and may even have insecticidal properties (Xue et al., 2003; Barnard and Xue, 2004; Kaufman et al., 2010). Moreover, geraniol has also been shown to be repellent to other insects such as houseflies, stable flies (Mann et al., 2010) and ticks (Weldon et al., 2011).

In previous experiments in Israel, 5\% geraniol candles were about twice as effective as those with $5 \%$ linalool and were about 5 times as effective as $5 \%$ citronella candles in protecting a person from being bitten by mosquitoes when used indoors (Müller et al., 2008b). When used outdoors to protect volunteers in a high biting pressure environment, the same 5\% geraniol candles reduced the mosquito pressure by an average of $56 \%$ over a distance of $1.0 \mathrm{~m}$. In a low biting pressure environment, geraniol candles reduced the mosquito pressure by an average of 62\% (Müller et al., 2008a). A similar study, also conducted in Israel, showed that geraniol (4-6 mg/h) released indoors by diffusers, reduced $C x$. pipiens mosquitoes caught by nearby CDC light traps by 36\% (SirakWizeman et al., 2008). The $C x$. pipiens mosquito carries WNV and was a key vector responsible for the New York outbreak in 1999, which rapidly swept across North America to the West Coast, north into southern Canada and south into the Caribbean and Latin America (Reisen and Brault, 2007).
Not surprisingly, protection of a human volunteer should be greater when they are situated closer to the source of the repellent, an assumption confirmed by Müller et al. (2008a), who found that increasing the distance between candle and subject to $2 \mathrm{~m}$ and $3 \mathrm{~m}$, greatly reduced repellency. This trial shows that a single misting unit, under optimal conditions, can reduce mosquitoes at a distance of $9 \mathrm{ft}(2.74 \mathrm{~m})$ by as much as $99 \%$ when used at 5.0-min intervals and even at 10 -min intervals, biting pressure reduction is still a comfortable $80 \%$. When used at $18 \mathrm{ft}(5.49 \mathrm{~m})$ from the subject, biting pressure is still reduced by $\sim 95 \%$ during 5.0 -min intervals, by $\sim 82 \%$ at 7.5 -min intervals, and by $\sim 67 \%$ at 10 -min intervals. Currently accepted guidelines require candles, coils, vaporizing mats or other such products to provide at least a $50 \%$ repellency rate to make a reliable claim that the product repels mosquitoes (Govere and Durrheim, 2007). Under the conditions in this study, the Terminix ${ }^{\circledR}$ ALLCLEAR ${ }^{\circledR}$ Mosquito Mister is well in excess of the $50 \%$ reduction required. Moreover, based on the area coverage results, and using these time intervals, the maximum protection distance of the Mosquito Mister probably exceeds $18 \mathrm{ft}$ with a coverage area well in excess of the $300 \mathrm{ft}^{2}$ claimed by the manufacturer. Keeping in mind the importance of the time interval in which the units mist to achieve a good protection level, the added function "mist now" allows the consumer to reduce the biting pressure according to his needs.

\section{References}

Barnard, D.R., Xue, R., 2004. Laboratory evaluation of mosquito repellents against Aedes albopictus, Culex nigripalpus, and Ochlerotatus triseriatus (Diptera: Culicidae). Journal of Medical Entomology 41, 726-730.

Barnard, D.R., Bernier, U.R., Xue, R., Debboun, M., Govere, M., 2007. Standard methods for testing mosquito repellents. In: Debboun, M., Frances, S.P., Strickman, D. (Eds.), Insect Repellents: Principles, Methods and Uses. CRC Press, Boca Raton, FL, pp. 103-110.

Choi, W.S., Park, B.S., Ku, S.K., Lee, S.E., 2002. Repellent activities of essential oils and monoterpenes against Culex pipiens pallens Coquillett. Journal of the American Mosquito Control Association 18, 348-351.

Cox, C., 2005. Plant-based mosquito repellents: making a careful choice. Journal of Pesticides Reform 25, 6-7.

EPA 712-C-99-369. December 1999. Product Performance Test Guidelines OPPTS 810.3700: Insect Repellents For Human Skin and Outdoor Premises.

Gerberg, E.J., Novak, R.J., 2007. Considerations on the use of botanically-derived repellent products. In: Debboun, M., Frances, S.P., Strickman, D. (Eds.), Insect Repellents: Principles, Methods and Uses. CRC Press, Boca Raton, FL, pp. 305-309.

Govere, M., Durrheim, D.N., 2007. Techniques for evaluating repellents. In: Debboun, M., Frances, S.P., Strickman, D. (Eds.), Insect Repellents: Principles, Methods and Uses. CRC Press, Boca Raton, FL, pp. 147-159.

Kaufman, P.E., Mann, R.S., Butler, J.F., 2010. Evaluation of semiochemical toxicity to Aedes aegypti, Ae. albopictus and Anopheles quadrimaculatus (Diptera: Culicidae). Pest Management Science 66, 497-504. 
Mann, R.S., Kaufman, P.E., Butlet, J.F., 2010. Evaluation of semiochemical toxicity to houseflies and stable flies (Diptera:Muscidae). Pest Management Science 66, 816-824.

Moore, S.J., Lenglet, A., Hill, N., 2007. Plant-based insect repellents. In: Debboun, M., Frances, S.P., Strickman, D. (Eds.), Insect Repellents: Principles, Methods and Uses. CRC Press, Boca Raton, FL, pp. 2-43.

Müller, G.C., Junnila, A., Kravchenko, V.D., Revay, E.E., Butler, J., Orlova, O.B., 2008a. Ability of essential oil candles to repel biting insects in high and low biting pressure environments. Journal of the American Mosquito Control Association 24, 154-160.

Müller, G.C., Junnila, A., Kravchenko, V.D., Revay, E.E., Butler, J., Schlein, Y., 2008 Indoor protection against mosquito and sand fly bites: a comparison between citronella, linalool and geraniol candles. Journal of the American Mosquito Control Association 24, 150-153.
Omolo, M.O., Okinyo, D., Ndiege, I.O., Lwande, W., Hassanali, A., 2004. Repellency of essential oils of some Kenyan plants against Anopheles gambiae. Phytochemistry 65, 2797-2802.

Reisen, W., Brault, A.C., 2007. West Nile virus in North America: perspectives on epidemiology and intervention. Pest Management Science 63, 641-646.

Weldon, P.J., Carroll, J.F., Kramer, M., Bedoukian, R.H., Coleman, R.E., Bernier, U.R., 2011. Anointing chemicals and hematophagous arthropods: responses by ticks and mosquitoes to Citrus (Rutaceae) peel exudates and monoterpene components. Journal of Chemical Ecology 37, 348-359.

Wirtz, R.A., Turrentine, J.D., Rutledge, L.C., 1980. Mosquito area repellents: laboratory testing of candidate materials against Aedes aegypti. Mosquito News 40, 432-439. 